\title{
J. J. Holst \\ Glucagon-like peptide-1: from extract to agent. The Claude Bernard Lecture, 2005
}

Received: 24 October 2005 / Accepted: 21 November 2005 / Published online: 14 January 2006

C) Springer-Verlag 2006

\begin{abstract}
The incretin hormones are intestinal polypeptides that enhance postprandial insulin secretion. Gastric inhibitory polypeptide (GIP) was initially thought to regulate gastric acid secretion, whereas glucagon-like peptide1 (GLP-1) was discovered as a result of a systematic search for intestinal insulinotropic products of proglucagon gene expression. The incretin effect is markedly impaired or absent in patients with type 2 diabetes because of decreased secretion of GLP-1 and a loss of the insulinotropic effects of GIP. Metabolic control can be restored or greatly improved by administration of exogenous GLP-1, but this peptide is almost immediately degraded by dipeptidyl peptidase IV (DPP-IV), and therefore has little clinical value. DPP-IV-resistant analogues (incretin mimetics) have been identified or developed, and inhibitors of DPP-IV have also proved effective in protecting endogenous GLP-1 (and GIP) from degradation. Both principles have been tested in clinical studies. The incretin mimetics, administered by sc injection, have demonstrated lasting improvement in $\mathrm{HbA}_{1} \mathrm{c}$ in patients insufficiently treated with conventional oral therapy, and their use has been associated with steady weight loss for up to 2 years. The DPP-IV inhibitors, given once or twice daily by mouth, also appear to provide lasting improvement in $\mathrm{HbA}_{1} \mathrm{c}$, but are weight-neutral. The first incretin mimetic has reached the market in the US, and applications for approval of the first inhibitors are expected to be filed early in 2006 .
\end{abstract}

Keywords Byetta - DPP-IV - Exendin · GIP · Glucagon-like · Incretin · Liraglutide · Proglucagon · Vildagliptin

\section{J. J. Holst ( $\bowtie)$}

Department of Medical Physiology,

The Panum Institute, University of Copenhagen,

Blegdamsvej 3,

DK-2200, Copenhagen, Denmark

e-mail: holst@mfi.ku.dk

Tel.: +45-3532-7518

Fax: $+45-3532-7537$
Abbreviations DPP-IV: dipeptidyl peptidase IV - GIP: gastric inhibitory polypeptide or glucose-dependent insulinotropic polypeptide - GLP: glucagon-like peptide

\section{Discovery of glucagon-like peptide-1}

Diabetologists have been interested in two aspects of the gut for the past 30 years. The first is the incretin effect, i.e. the amplification of nutrient-induced insulin secretion by hormones from the gut [1], and the second has been the occurrence of glucagon-producing L-cells in the gut. Could the two have anything to do with each other? Glucagon from the pancreas was known to be able to stimulate insulin secretion in man [2], but the intestinal glucagon immunoreactive cells did not appear to produce real glucagon, but substances that could only be measured by certain glucagon radioimmunoassays directed against the mid region of the molecule. This was because the 'gut glucagons' contained the entire glucagon sequence [3, 4]. Indeed, as early as 1973 we found that individuals who suffered from postprandial reactive hypoglycaemia had exaggerated secretion of 'gut glucagon' $[5,6]$. The predominant molecule of the 'gut glucagons' turned out to be a peptide of 69 amino acids, designated glicentin, which, as predicted [3], contained the full glucagon sequence (residues 33-61), but this molecule had no effect on insulin secretion. A truncated form, corresponding to residues 33-69 [4], today referred to as oxyntomodulin [7], was quite effective in stimulating insulin secretion [8], as would be expected of a peptide in which the full glucagon sequence occupies its $\mathrm{N}$ terminus. Nevertheless, it was not as potent as glucagon. It was therefore questionable whether this molecule, which circulates in low concentrations [9], would contribute to the incretin effect.

Around 1973, the peptide gastric inhibitory polypeptide (GIP) had been shown to stimulate insulin secretion $[10,11]$ and was henceforth called glucose-dependent insulinotropic polypeptide, thus preserving the acronym. It was also shown to be likely to function as an important incretin hormone in mimicry experiments [12], in which 
endogenous hormone concentrations are mimicked by infusion of exogenous hormone. But it was clear that there had to be another incretin hormone. Immunoneutralisation studies, carried out in vitro and in vivo in rats, demonstrated that removal of GIP did not eliminate the incretin effect $[13,14]$, while in patients with intestinal resections, the incretin effect correlated not with GIP secretion, but with the residual length of ileum, in which the density of L-cells is highest. Again, the L-cell came under scrutiny.

Because of the presence of the full glucagon sequence in glicentin, we reasoned at that time that this molecule might represent proglucagon, the biosynthetic precursor of glucagon, and this belief was strengthened when we found small amounts of glicentin to be present in the pancreas [15], and were able to demonstrate parallel secretion of glucagon and the N-terminal part of glicentin after glucagon had been cleaved off [16]. However, translation studies in cell-free systems indicated that proglucagon had more than 69 amino acids, and in $1982 \mathrm{~K}$. Lund, working in J. Habener's laboratory, managed to deduce the sequence of proglucagon from anglerfish (chosen for the ease of isolating pancreatic endocrine tissue contained in the socalled Brockmann bodies) [17]. This molecule contained a glucagon-like peptide (GLP) in addition to anglerfish glucagon, and therefore nurtured the notion that the proglucagon gene might encode more than one bioactive peptide. Finally, in 1983, G. Bell and co-workers cloned the hamster and human proglucagon genes $[18,19]$ and were thereby able to deduce the human proglucagon sequence. In agreement with the prediction, its N-terminus consisted of the full sequence of glicentin, containing also the glucagon sequence. But surprisingly, the molecule contained not one, but two additional glucagon like-sequences, henceforth designated GLP-1 and GLP-2. These sequences were flanked by pairs of basic amino acids, predicted posttranslational processing sites, suggesting that the two peptides might be cleaved out of the precursor to be released to the blood stream. This turned out to be the case for proglucagon produced in the intestinal L-cells, whereas proglucagon produced in the pancreatic alpha cells was cleaved into glucagon and a large C-terminal fragment, the socalled major proglucagon fragment $[20,21]$.

The problem was that, as demonstrated in experiments using the isolated perfused pancreas, neither of the GLPs stimulated insulin secretion. GLP-2 has since been shown to function as an important growth factor for the gut [22], and is currently being evaluated as a therapeutic agent for intestinal insufficiency [23]. Having established radioimmunoassays for the glucagon-like peptides, we were now able to study the insulin-stimulating effect of a peptide that we isolated from gut extracts on the basis of its GLP-1 immunoreactivity. This peptide was strongly insulinotropic. When sequenced, we found that it represented a truncated form of GLP-1, corresponding to residues 7-37 [24] of the predicted molecule. Clearly, natural GLP-1 was not processed at the dibasic site in proglucagon, but at a monobasic site corresponding to residue no. 77 in proglucagon [24]. In addition, natural GLP-1 turned out to be C-terminally amidated [25], hence the designation 'GLP-1
(7-36) amide.' There was no doubt that a new potent insulinotropic molecule had been identified [26, 27]. S. Bloom and co-workers [28] quickly performed mimicry experiments in human volunteers, and showed that apparently physiological concentrations of the new peptide powerfully stimulated glucose-induced insulin secretion: the missing incretin hormone had been found.

\section{GLP-1 and diabetes treatment}

Initially, no attempt was made to use GLP-1 for diabetes treatment: the disappointing attempts to stimulate insulin secretion in type 2 diabetic subjects with GIP had not been forgotten [29]. It was, however, soon realised that GLP-1 was different, for unlike GIP, GLP-1 powerfully inhibited glucagon secretion [30]. Furthermore, GLP-1 not only stimulated glucose-induced insulin secretion, but also all steps of insulin biosynthesis and insulin gene expression [31]. GLP-1 also turned out to have powerful effects on gastrointestinal secretion and motility [32,33], and it was shown that inhibition of gastric emptying had strong effects on postprandial glucose excursions [34] in healthy subjects and patients with type 2 diabetes [35]. In addition, GLP-1 was shown to inhibit appetite and food intake, both in healthy individuals [36], and in patients with type 2 diabetes [37]. These gastrointestinal 'ileal brake' effects of GLP-1 may in fact be the most important actions of the hormone under physiological conditions [38]. It was eventually demonstrated that, unlike GIP, intravenous infusion of GLP-1 had dramatic effects on insulin secretion and blood glucose in patients with type 2 diabetes and was capable of completely normalising fasting blood glucose levels, even in patients with long-standing type 2 diabetes and $\mathrm{HbA}_{1 \mathrm{c}}$ levels of $11 \%$ [39-42].

From this point on, laboratories in academia and industry strove to turn this molecule into a suitable pharmaceutical agent. It soon emerged that simple subcutaneous injections were ineffective. There was an effect on insulin and blood glucose, but this was both transient and weak $[43,44]$. The explanation for this was that the molecule is broken down extremely rapidly after both subcutaneous and intravenous administration [45-47]. This mechanism involved the ubiquitous enzyme, dipeptidyl peptidase IV (DPP-IV) [45], as predicted by R. Mentlein in Kiel [48], who went on to show that GLP-1 is a substrate for this enzyme. The degradation is truly extensive, which means that the peptide has a plasma half-life of 1 to $2 \mathrm{~min}$ and a clearance of 5 to $10 \mathrm{l} / \mathrm{min}$, two to three times cardiac output [49]. For practical diabetes treatment, there were now three possibilities: (1) to provide GLP-1 continuously; (2) to develop stable analogues of GLP-1 or agonists of the GLP1 receptors; and (3) to try to inhibit the enzyme, DPP-IV.

\section{The effect of continuously administered GLP-1}

In early, rather heroic studies, GLP-1 was given as continuous intravenous infusion to a relatively large number of 
people with type 2 diabetes $[50,51]$. Administration was at four different infusion rates: 4, 8, 16 and $24 \mathrm{ng} \mathrm{kg}^{-1} \mathrm{~min}^{-1}$ (approximately: 1.2, 2.4, 4.8 and $9.6 \mathrm{pmol} \mathrm{kg}^{-1} \mathrm{~min}^{-1}$ ). Infusion rates of $4.8 \mathrm{pmol} \mathrm{kg}^{-1} \mathrm{~min}^{-1}$ and above caused nausea and vomiting, and were therefore abandoned. The two lower infusion rates were practically free from side effects and effective in reducing diurnal blood glucose levels, with similar efficacy on the 1 st and the 7 th day. Termination of the infusion resulted in an immediate return of blood glucose concentrations to pre-infusion levels. Another study showed that overnight intravenous infusion of GLP-1 not only returned fasting glucose values towards normal, but had the same effect upon postprandial plasma glucose concentrations when the infusion was continued [52].

Intravenous infusions are clearly not of any clinical utility, and M. Zander in our laboratory [53] therefore carried out a clinical study, in which a group of patients with type 2 diabetes received GLP-1 or saline as a continuous subcutaneous infusion (using insulin pumps) for 6 weeks. These patients were assessed before, after 1 week and after 6 weeks of treatment. No changes were observed in the saline-treated control group, whereas fasting and average plasma glucose concentrations were lowered by approximately $5 \mathrm{mmol} / 1$ in the GLP-1 group. In this group $\mathrm{HbA}_{1} \mathrm{c}$ fell by $1.2 \%$, free fatty acids were significantly lowered, and the patients lost $2 \mathrm{~kg}$ in weight. Furthermore, insulin sensitivity, as determined by a hyperinsulinaemiceuglycaemic clamp, almost doubled, insulin secretion capacity (measured using a $30 \mathrm{mmol} / \mathrm{l}$ glucose clamp + arginine) greatly improved, and a first-phase response was restored. There was no significant difference between results obtained after 1 and 6 weeks treatment, but there was a tendency towards further improvement of plasma glucose as well as insulin secretion. The treatment was free from side effects, which did not differ between saline and GLP-1 treated patients. Despite the marked metabolic improvement, plasma glucose levels were not completely normalised, but the dose given (4.8 $\mathrm{pmol} \mathrm{kg}^{-1} \mathrm{~min}^{-1}$ ) may not have been optimal. A further study showed that higher infusion rates were even more efficacious and side effects were not prohibitive [54]. This work, confirmed by others [55], provided 'proof-of-concept' for the principle of GLP-1-based therapy of type 2 diabetes mellitus. However, as with continuous subcutaneous infusion of insulin, this therapeutic approach was limited in its application, and alternative approaches were therefore explored.

\section{Stable analogues and GLP-1 receptor activators}

Initial studies showed that GLP-1 could be protected from degradation by DPP-IV, without loss of biological activity, simply by substituting amino acid residue no. 2 (Ala) with other amino acids with short side chains, e.g. glycine, serine, threonine or alpha-amino-isobutyric acid [56]. As predicted [57], however, this only extended the half life of the molecule by a few minutes, too short for single subcutaneous injections. The explanation for this is the dra- matic renal clearance of GLP-1, with extraction ratios up to $70 \%$.

Meanwhile a molecule had been discovered, which is a full agonist for the GLP-1 receptor, is resistant to DPP-IV, and is apparently cleared in the kidneys only by glomerular filtration [58]. Its name: exendin-4. In the 1970s many biologists were searching for new biologically active peptides, inspired by the success of the Italian pharmacologists, Erspamer and Melchiorri, who found numerous new active peptides in the skin of amphibia [59], many of which had mammalian counterparts. A particularly successful approach was adopted by K. Tatemoto and V. Mutt who, noting that many biologically active peptides carry a C-terminal amidation, developed an assay for C-terminally amidated peptides, and identified several new important peptides, including vasoactive intestinal polypeptide (VIP) and neuropeptide Y (NPY) [60]. Using a similar approach, J. Raufman and J. Eng noted the importance of the Nterminal histidine in peptides of the secretin-glucagon family, and developed an assay for peptides with this Nterminus, which they applied to the venom of the Heloderma lizards, Heloderma suspectum (the Gila monster; Fig. 1) and Heloderma horridum, which had already been shown to contain the biologically active peptides helospectin and helodermin. In $H$. horridum, they identified a new peptide, which they named exendin-3, in order to identify it as the third peptide with endocrine activity (on pancreatic acinar tissue) to be found in an exocrine secretion of Heloderma lizards [61]. In venom from $H$. suspectum, a similar peptide, differing from exendin-3 by only two amino acids near the N-terminus, was identified and named exendin-4 [62]. This peptide, although also capable of activating adenylate cyclase activity in pancreatic acini, clearly differed from exendin-3 in its actions. In a search for mammalian counterparts of exendin-4, it was noted that GLP-1 had similar activities and appears to compete with exendin-4 for binding to the acini [63]. In a subsequent collaboration with R. Goke et al. from Marburg,

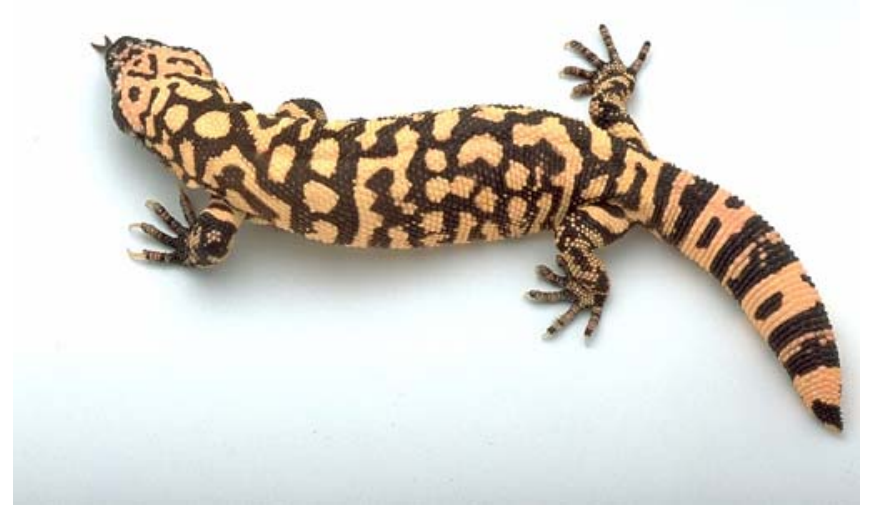

Fig. 1 The Gila monster (Heloderma suspectum), a poisonous lizard from the deserts of Arizona. In 1992, J. Raufman and coworkers isolated exendin-4 from an exocrine secretion (the saliva) of this creature. Exendin-4 is the 4th peptide with endocrine actions (on the pancreas), and is now registered as an antidiabetic agent under the name of Byetta 
Germany, it was unequivocally established that exendin-4 acts as a high potency agonist at the GLP-1 receptor of insulin-secreting beta cells [64]. It was also established that a fragment of the exendins, exendin 9-39, identified during a systematic analysis of the activities of truncated forms of exendin-3 [65], was a high potency antagonist [64], a finding that proved most valuable in later studies of the physiological role of GLP-1.

Subsequent research has established that exendin-4 is not the GLP-1 of the Gila Monster [66] (it has its own GLP1 , which is much closer to mammalian GLP-1), and that a mammalian counterpart does not seem to exist. A single subcutaneous injection of $10 \mu \mathrm{g}$, the recommended dose, has biological effects for some 5 to $7 \mathrm{~h}$ in humans [67]. Synthetic exendin-4, now known as exenatide, is therefore given twice daily. This apart, exenatide seems to share all of the effects of native GLP-1 [58]. The compound has been tested in several clinical trials, most recently in three controlled pivotal phase III studies involving 1,494 patients, in whom exenatide was given for 30 weeks as an add-on therapy to type 2 diabetic patients inadequately treated with sulfonylureas [68], metformin [69] or a combination of metformin and sulfonylureas [70]. After 30 weeks of treatment, fasting blood glucose concentrations fell, $\mathrm{HbA}_{1} \mathrm{c}$ levels were reduced by approximately $0.8 \%$ overall and to or below $7 \%$ in 41,46 and $34 \%$ of the patients in the three groups. Adverse effects were mild and generally gastrointestinal. Mild hypoglycaemia was noted in 28 to $36 \%$ of patients also receiving sulfonylurea. An important result was a significant, dose-dependent and progressive weight loss of $1.6 \mathrm{~kg}$ (patients treated with sulfonylurea and sulfonylurea + metformin) and $2.8 \mathrm{~kg}$ (metformin treatment) from baseline. In open-label extensions of these studies, exenatide was given for a total of 82 weeks with continued effects on $\mathrm{HbA}_{1} \mathrm{c}$ and body weight (details: http://www.amylin.com). However, some patients (about $38 \%$ of patients after 30 weeks) appear to develop low-titre antibodies against exenatide, and 6\% developed antibodies with higher titres. In about half of these, the glucose-lowering effect of exenatide appeared attenuated. The three studies provided the basis for an application for approval of exenatide as a new drug for the treatment of diabetes, and this was approved by the FDA in April 2005. Information about the new drug, named Byetta, is available from the web site of the company (http://www. BYETTA.com). Exenatide thus represents an efficacious supplement to failing conventional oral antihyperglycaemic agents, and the sustained effect observed in the extension studies and its continued weight-lowering effects must be considered very promising.

Other analogues currently in clinical development include slightly modified versions of the GLP-1 molecule that attach to albumin, thereby acquiring the pharmacokinetic profile of albumin. One such analogue is liraglutide, which consists of a slightly modified GLP-1 sequence with a palmitoyl chain attached. This confers affinity for and binding to albumin and, as a result, protects the molecule both from DPP-IV and renal elimination. The plasma half life of this compound is $12 \mathrm{~h}$, and it therefore provides exposure for more than $24 \mathrm{~h}$ after a single injection [71]. The compound seems to possess all of the activities of native GLP-1 [72]. A recent report describes administration of increasing doses of liraglutide to patients with type 2 diabetes for 3 months [73]. Liraglutide lowered fasting blood glucose and $\mathrm{HbA}_{1} \mathrm{c}$ dose-dependently (by up to $0.75 \%$ points from a base line level of $7.6 \%$ ), and also significantly lowered body weight in some doses. There were very few side effects, and no antibody formation. The strength of this compound seems to be its attractive pharmacokinetic profile, providing a rather stable plateau of active compound in plasma upon single daily injections. In this way, side effects (nausea, vomiting) associated with large excursions in the plasma concentration of more rapidly metabolised compounds after subcutaneous injection may be avoided. In a recent study [74], liraglutide was given in doses up to $2 \mathrm{mg}$ once daily in a 5-week period with weekly up-titrations to patients with high $\mathrm{HbA}_{1} \mathrm{c}$ levels $(8-10 \%)$. Particularly when given in addition to metformin, liraglutide powerfully reduced fasting glucose levels (from 13 to $9 \mathrm{mmol} / \mathrm{l}$ ) and resulted in weight loss of $2.4 \%$. Gastrointestinal side effects were transient and led to withdrawal in only $4 \%$ of the patients. A number of additional GLP-1 analogues are in clinical development, but little information is currently available for these.

\section{Inhibitors of DPP-IV}

The therapeutic use of inhibitors of DPP-IV, the enzyme responsible for inactivation of GLP-1, as an antihyperglycaemic agent was first proposed in 1995 [46], based on the finding that GLP-1 seems uniquely sensitive to cleavage by DPP-IV. Compounds of this class have now reached phase III clinical trials. A DPP-IV inhibitor can completely prevent the N-terminal degradation of GLP-1 that occurs in vivo, resulting in significant enhancement of its insulinotropic activity [75]. Studies in Vancouver diabetic fatty rats have shown that chronic oral administration of the DPP-IV inhibitor, isoleucine thiazolidide (P32/98), for 12 weeks improves glucose tolerance, insulin sensitivity and beta cell responsiveness [76]. The longer-acting inhibitor, FE 999011 continuously inhibited plasma DPP-IV activity and not only normalised glucose excursions after oral glucose administration in insulin-resistant Zucker obese rats, but also delayed the onset of hyperglycaemia in Zucker diabetic fatty rats [77]. These effects were, at least in part, attributed to increased levels of intact GLP-1. Increased intact GLP-1 concentrations were further implicated in the improved islet function seen after chronic treatment of high-fat-fed (glucose-intolerant and insulin-resistant) mice with valinepyrrolidide [78]. Additional support for the involvement of DPP-IV inhibition in mediating glucose tolerance comes from studies in Fischer rats, which have a catalytically inactive DPP-IV molecule, and CD26 knockout mice with a targeted disruption of the gene encoding DPP-IV. Such animals have improved glucose tolerance compared to their wild-type counterparts [79-81]. In DPP-IV-negative Fischer rats and DPP-IV inhibitor-treated control animals, 
the impaired glucose tolerance that normally develops with ageing is prevented [81, 82], while the lack of DPPIV protects both Fischer rats and CD26 knockout mice from diet (high fat)-induced insulin resistance and glucose intolerance [82-84]. Once again, these effects are believed to involve preservation of endogenous GLP-1, because intact GLP-1 concentrations are elevated.

After these promising preclinical studies, the first clinical proof-of-concept was obtained using the short-acting inhibitor, NVP-DPP728 [85]. When given twice or three times daily for 4 weeks in patients with relatively mild type 2 diabetes (mean $\mathrm{HbA}_{1} \mathrm{c} 7.4 \%$ ), both fasting and prandial glucose levels were lowered significantly, resulting in a $0.5 \%$ reduction in $\mathrm{HbA}_{1} \mathrm{c}$; despite the fall in glycaemia, fasting and post-prandial insulin levels were sustained. NVP-DPP728 appeared to be well tolerated, with only minor adverse events. Some of these symptoms (pruritis and nasopharyngitis) did, however, seem to be drugrather than class-specific, because they were not reported for another inhibitor, LAF237, subsequently developed by the manufacturer of NVP-DPP728. NVP-DPP728 has now been dropped in favour of LAF237, which is longer-acting and suitable for once-daily administration. A recent clinical study showed LAF237 to have a pharmacodynamic profile similar to that of its predecessor [86]. The mechanism of action was suggested to be incretin-mediated, because LAF237 treatment increased baseline and prandial active GLP-1 levels. As with NVP-DPP728, insulin levels were not actually increased, but interestingly, glucagon levels were significantly suppressed. Most recently, clinical data have emerged from a 52-week study in patients already on metformin treatment [87]. LAF 237 significantly lowered $\mathrm{HbA}_{1} \mathrm{c}$ levels from $7.7 \%$ to approximately $7 \%$ after 3 months of treatment, and this level was maintained for the remaining period, whereas a significant increase was noted in the control group, resulting in a difference between placebo- and LAF-237-treated patients of $1.1 \%$. In addition, meal-induced insulin secretion was impaired in the placebo group and remained unaltered in the treatment group, in spite of significantly lower glucose levels. Sideeffects were inconspicuous.

In contrast to the results obtained with the GLP-1 analogues, no change in body weight was seen with DPP-IV inhibition. The binding kinetics, type of inhibition and selectivity with respect to other peptidases for the inhibitor (now called vildagliptin) have been reported [88]. The inhibitor significantly increased insulin secretion rate (socalled insulin secretory tone) at $7 \mathrm{mmol} / 1$ glucose, and inhibited glucagon secretion, while increasing levels of active GLP-1 and GIP [89]. According to the makers' website (http://www.novartis.com), phase III clinical trials are in progress, and filing for FDA approval is expected in 2006. An inhibitor from another company, MK-0431 (sitagliptin), is also in phase III trials (details: http://www. Merck.com), but so far, little is known about this compound [90]. According to their respective websites, three other companies are now developing DPP-IV inhibitors (see: http://www.GSK.com [phase I]; http://www.BMS. com [saxagliptin; phase III]; and http://www.Prosidion. com [PSN9301; phase II]), with several other companies reportedly having a DPP-IV inhibitor programme.

\section{Protective effects of GLP-1}

Thus, both GLP-1 analogues, receptor activators and DPPIV inhibitors have shown promising potential as antihyperglycaemic agents. The most important question, whether or not this incretin-based approach to treating type 2 diabetes will be able to slow or prevent the apparently inevitable progression of the disease, remains to be answered. But in this respect, the GLP-1-based therapies possess a unique potential: GLP-1 has trophic effects on beta cells [91]. Not only does it stimulate beta cell proliferation $[92,93]$, it also enhances the differentiation of new beta cells from progenitor cells in the pancreatic duct epithelium [94] and, perhaps most importantly, GLP-1 is capable of inhibiting apoptosis of beta cells including human beta cells [95]. Since the normal number of beta cells is maintained in a balance between apoptosis and proliferation, this observation is of considerable interest, and raises the possibility that GLP-1 could be useful in conditions in which beta cell apoptosis is increased. The complicated mechanisms whereby GLP-1 may exert these effects on beta cells were reviewed recently [96].

For obvious reasons, it is difficult to estimate the protective effects of GLP-1 on beta cells in humans, and it might be argued that this is irrelevant if the effect is not translated into improved glycaemic control. So is there any clinical evidence that a GLP-1-based therapy really does have protective effects on beta cells? One problem is that the rate at which beta cell proliferation occurs in humans is not known. Or said in another way: how long should one wait for such effects to unfold? Nevertheless, there are some data that may be of use. In the study where LAF 237 was administered for 52 weeks to patients inadequately treated with metformin, the LAF group showed a sustained improvement in $\mathrm{HbA}_{1} \mathrm{c}$ levels throughout the 52-week period, whereas an increase was observed in the control group [87]. Similarly, over 82 weeks of treatment with exenatide, $\mathrm{HbA}_{1} \mathrm{c}$ levels remained constant at approximately 7\%, although - according to the UKPDS - an increase would have been expected over this time span. These sustained effects could be the first indications that GLP-1 has beta-cell-protective effects that persist after the plateau reached 3 to 4 months after initiation of therapy. The reason for this remains unclear, and it may be that continued exposure to GLP-1 (which cannot be provided with exenatide given twice daily) or higher concentrations of active GLP-1 than those achievable by DPP-IV inhibition are required for further improvements in metabolic control to occur. At any rate, these observations tell us that a GLP-1-based therapy should be started as early in the clinical course as possible, before beta cell function has deteriorated to unacceptable levels. 


\section{Conclusion}

Two therapeutic principles of great promise have emerged from the finding that intestinal extracts contain an incretin hormone with insulinotropic action in type 2 diabetes. One, the DPP-IV inhibitors, involves administration of a single tablet once daily, which, so far, possesses no class-related side effects. Although apparently effective as antihyperglycaemic agents, the DPP-IV inhibitors may be of particular value for the prevention or delay of overt diabetes, and might therefore be given to individuals at risk of developing type 2 diabetes. With the other therapeutic principle, the injectables, higher levels of active substance are reached compared to the DPP-IV inhibitors, and, in addition, they promote weight loss. They might, therefore, be particularly useful for the treatment of already established disease. In any case, GLP-1-based therapies have added new colours to the palette of drugs at the diabetologist's disposal.

Acknowledgements The author wishes to acknowledge the invaluable contributions of the many colleagues and friends who contributed to the studies reviewed above. In particular, I wish to thank C. Ørskov, C. Deacon and M. Nauck. Financial support was obtained from, among others, the Danish Medical Research Council, The NovoNordisk Foundation and European Foundation for the Study of Diabetes.

\section{References}

1. Vilsboll T, Holst JJ (2004) Incretins, insulin secretion and Type 2 diabetes mellitus. Diabetologia 47:357-366

2. Samols E, Marri G, Marks V (1965) Promotion of insulin secretion by glucagon. Lancet 40:415-416

3. Holst JJ (1980) Evidence that glicentin contains the entire sequence of glucagon. Biochem J 187:337-343

4. Holst JJ (1982) Evidence that enteroglucagon (II) is identical with the C-terminal sequence (residues 33-69) of glicentin. Biochem J 207:381-388

5. Holst JJ, Hending LG, Rehfeld JF (1973) Gut glucagon and reactive hypoglycaemia. Lancet 1:1008

6. Rehfeld JF, Heding LG, Holst JJ (1973) Increased gut glucagon release as pathogenetic factor in reactive hypoglycaemia? Lancet 1:116-118

7. Bataille D, Coudray AM, Carlqvist M, Rosselin G, Mutt V (1982) Isolation of glucagon-37 (bioactive enteroglucagon/ oxyntomodulin) from porcine jejuno-ileum. Isolation of the peptide. FEBS Lett 146:73-78

8. Baldissera FG, Holst JJ, Knuhtsen S, Hilsted L, Nielsen OV (1988) Oxyntomodulin (glicentin-(33-69)): pharmacokinetics, binding to liver cell membranes, effects on isolated perfused pig pancreas, and secretion from isolated perfused lower small intestine of pigs. Regul Pept 21:151-166

9. Holst JJ (1983) Molecular heterogeneity of glucagon in normal subjects and in patients with glucagon-producing tumours. Diabetologia 24:359-365

10. Brown JC (1982) Gastric inhibitory polypeptide. Monogr Endocrinol 24:1-88

11. Dupre J, Ross SA, Watson D, Brown JC (1973) Stimulation of insulin secretion by gastric inhibitory polypeptide in man. J Clin Endocrinol Metab. 37:826-828

12. Nauck M, Schmidt WE, Ebert R et al (1989) Insulinotropic properties of synthetic human gastric inhibitory polypeptide in man: interactions with glucose, phenylalanine, and cholecystokinin-8. J Clin Endocrinol Metab 69:654-662
13. Ebert R, Unger H, Creutzfeldt W (1983) Preservation of incretin activity after removal of gastric inhibitory polypeptide (GIP) from rat gut extracts by immunoadsorption. Diabetologia 24:449-454

14. Ebert R, Creutzfeldt W (1982) Influence of gastric inhibitory polypeptide antiserum on glucose-induced insulin secretion in rats. Endocrinology 111:1601-1606

15. Sheikh SP, Baldissera FG, Karlsen FO, Holst JJ (1985) Glicentin is present in the pig pancreas. FEBS Lett 179:1-6

16. Moody AJ, Holst JJ, Thim L, Jensen SL (1981) Relationship of glicentin to proglucagon and glucagon in the porcine pancreas. Nature 289:514-516

17. Lund PK, Goodman RH, Dee PC, Habener JF (1982) Pancreatic preproglucagon cDNA contains two glucagon-related coding sequences arranged in tandem. Proc Natl Acad Sci USA 79:345-349

18. Bell GI, Santerre RF, Mullenbach GT (1983) Hamster preproglucagon contains the sequence of glucagon and two related peptides. Nature 302:716-718

19. Bell GI, Sanchez-Pescador R, Laybourn PJ, Najarian RC (1983) Exon duplication and divergence in the human preproglucagon gene. Nature 304:368-371

20. Orskov C, Holst JJ, Knuhtsen S, Baldissera FG, Poulsen SS, Nielsen OV (1986) Glucagon-like peptides GLP 1 and GLP 2, predicted products of the glucagon gene, are secreted separately from pig small intestine but not pancreas. Endocrinology 119: $1467-1475$

21. Mojsov S, Heinrich G, Wilson IB, Ravazzola M, Orci L, Habener JF (1986) Preproglucagon gene expression in pancreas and intestine diversifies at the level of post-translational processing. J Biol Chem. 261:11880-11889

22. Drucker DJ, Erlich P, Asa SL, Brubaker PL (1996) Induction of intestinal epithelial proliferation by glucagon-like peptide 2 . Proc Natl Acad Sci USA 93:7911-7916

23. Jeppesen PB, Hartmann B, Thulesen J et al (2001) Glucagonlike peptide 2 improves nutrient absorption and nutritional status in short-bowel patients with no colon. Gastroenterology 120:806-815

24. Holst JJ, Orskov C, Nielsen OV, Schwartz TW (1987) Truncated glucagon-like peptide I, an insulin-releasing hormone from the distal gut. FEBS Lett 211:169-174

25. Orskov C, Bersani M, Johnsen AH, Hojrup P, Holst JJ (1989) Complete sequences of glucagon-like peptide-1 from human and pig small intestine. J Biol Chem 264:12826-12829

26. Holst JJ, Orskov C, Schwartz TW, Buhl T, Baldissera F (1986) Proglucagon 78-107, a potent insulinotropic hormone from the lower small intestine. Diabetologia 29:549A (Abstract)

27. Mojsov S, Weir GC, Habener JF (1987) Insulinotropin: glucagon-like peptide I (7-37) co-encoded in the glucagon gene is a potent stimulator of insulin release in the perfused rat pancreas. J Clin Invest 79:616-619

28. Kreymann B, Williams G, Ghatei MA, Bloom SR (1987) Glucagon-like peptide-1 7-36: a physiological incretin in man. Lancet 2:1300-1304

29. Krarup T (1988) Immunoreactive gastric inhibitory polypeptide. Endocr Rev 9:122-134

30. Orskov C, Holst JJ, Nielsen OV (1988) Effect of truncated glucagon-like peptide-1 [proglucagon-(78-107) amide] on endocrine secretion from pig pancreas, antrum, and nonantral stomach. Endocrinology 123:2009-2013

31. Fehmann HC, Habener JF (1992) Insulinotropic hormone glucagon-like peptide-I(7-37) stimulation of proinsulin gene expression and proinsulin biosynthesis in insulinoma beta TC-1 cells. Endocrinology 130:159-166

32. Schjoldager BT, Mortensen PE, Christiansen J, Orskov C, Holst JJ (1989) GLP-1 (glucagon-like peptide 1) and truncated GLP1, fragments of human proglucagon, inhibit gastric acid secretion in humans. Dig Dis Sci 34:703-708

33. Wettergren A, Schjoldager B, Mortensen PE, Myhre J, Christiansen J, Holst JJ (1993) Truncated GLP-1 (proglucagon 78-107-amide) inhibits gastric and pancreatic functions in man. Dig Dis Sci 38:665-673 
34. Nauck MA, Niedereichholz U, Ettler R et al (1997) Glucagonlike peptide 1 inhibition of gastric emptying outweighs its insulinotropic effects in healthy humans. Am J Physiol 273: E981-E988

35. Willms B, Werner J, Holst JJ, Orskov C, Creutzfeldt W, Nauck MA (1996) Gastric emptying, glucose responses, and insulin secretion after a liquid test meal: effects of exogenous glucagon-like peptide-1 (GLP-1)-(7-36) amide in type 2 (noninsulin-dependent) diabetic patients. J Clin Endocrinol Metab 81:327-332

36. Flint A, Raben A, Astrup A, Holst JJ (1998) Glucagon-like peptide 1 promotes satiety and suppresses energy intake in humans. J Clin Invest 101:515-520

37. Gutzwiller JP, Drewe J, Goke B et al (1999) Glucagon-like peptide-1 promotes satiety and reduces food intake in patients with diabetes mellitus type 2. Am J Physiol 276:R1541-R1544

38. Holst JJ (1999) Glucagon-like peptide 1(GLP-1): an intestinal hormone signalling nutritional abundance, with an unusual therapeutic potential. Trends Endocrinol Metab 10:229-234

39. Gutniak M, Orskov C, Holst JJ, Ahren B, Efendic S (1992) Antidiabetogenic effect of glucagon-like peptide-1 (7-36)amide in normal subjects and patients with diabetes mellitus. N Engl J Med 326:1316-1322

40. Nathan DM, Schreiber E, Fogel H, Mojsov S, Habener JF (1992) Insulinotropic action of glucagonlike peptide-I-(7-37) in diabetic and nondiabetic subjects. Diabetes Care 15:270-276

41. Nauck MA, Kleine N, Orskov C, Holst JJ, Willms B, Creutzfeldt W (1993) Normalization of fasting hyperglycaemia by exogenous glucagon-like peptide 1 (7-36 amide) in type 2 (non-insulin-dependent) diabetic patients. Diabetologia 36: 741-744

42. Nauck MA, Heimesaat MM, Orskov C, Holst JJ, Ebert R, Creutzfeldt W (1993) Preserved incretin activity of glucagonlike peptide 1 [7-36 amide] but not of synthetic human gastric inhibitory polypeptide in patients with type- 2 diabetes mellitus. J Clin Invest 91:301-307

43. Nauck MA, Wollschlager D, Werner J et al (1996) Effects of subcutaneous glucagon-like peptide 1 (GLP-1 [7-36 amide]) in patients with NIDDM. Diabetologia 39:1546-1553

44. Juntti-Berggren L, Pigon J, Karpe F et al (1996) The antidiabetogenic effect of GLP-1 is maintained during a 7-day treatment period and improves diabetic dyslipoproteinemia in NIDDM patients. Diabetes Care 19:1200-1206

45. Deacon CF, Johnsen AH, Holst JJ (1995) Degradation of glucagon-like peptide-1 by human plasma in vitro yields an $\mathrm{N}$ terminally truncated peptide that is a major endogenous metabolite in vivo. J Clin Endocrinol Metab 80:952-957

46. Deacon CF, Nauck MA, Toft-Nielsen M, Pridal L, Willms B, Holst JJ (1995) Both subcutaneously and intravenously administered glucagon-like peptide I are rapidly degraded from the $\mathrm{NH}_{2}$-terminus in type II diabetic patients and in healthy subjects. Diabetes 44:1126-1131

47. Kieffer TJ, McIntosh CH, Pederson RA (1995) Degradation of glucose-dependent insulinotropic polypeptide and truncated glucagon-like peptide 1 in vitro and in vivo by dipeptidyl peptidase IV. Endocrinology 136:3585-3596

48. Mentlein R, Gallwitz B, Schmidt WE (1993) Dipeptidyl-peptidase IV hydrolyses gastric inhibitory polypeptide, glucagonlike peptide-1(7-36)amide, peptide histidine methionine and is responsible for their degradation in human serum. Eur J Biochem 214:829-835

49. Vilsboll T, Agerso H, Krarup T, Holst JJ (2003) Similar elimination rates of glucagon-like peptide-1 in obese type 2 diabetic patients and healthy subjects. J Clin Endocrinol Metab 88:220-224

50. Larsen J, Jallad J, Damsbo P (1996) One-week continuous infusion of GLP-1(7-37) improves glycemic control in NIDDM. Diabetes 45:233A (Abstract)
51. Larsen J, Hylleberg B, Ng K, Damsbo P (2001) Glucagon-like peptide-1 infusion must be maintained for $24 \mathrm{~h} /$ day to obtain acceptable glycemia in type 2 diabetic patients who are poorly controlled on sulphonylurea treatment. Diabetes Care 24: 1416-1421

52. Rachman J, Barrow BA, Levy JC, Turner RC (1997) Nearnormalisation of diurnal glucose concentrations by continuous administration of glucagon-like peptide-1 (GLP-1) in subjects with NIDDM. Diabetologia 40:205-211

53. Zander M, Madsbad S, Madsen JL, Holst JJ (2002) Effect of 6week course of glucagon-like peptide 1 on glycaemic control, insulin sensitivity, and beta-cell function in type 2 diabetes: a parallel-group study. Lancet 359:824-830

54. Ehlers MRW, Roderick EH, Schneider RL, Kipnes MS (2002) Continuous subcutaneous infusion of recombinant GLP-1 for 7 days dose-dependently improved glycemic controls in type 2 diabetes. Diabetes 51:A579 (Abstract)

55. Meneilly GS, Greig N, Tildesley H, Habener JF, Egan JM, Elahi D (2003) Effects of 3 months of continuous subcutaneous administration of glucagon-like peptide 1 in elderly patients with type 2 diabetes. Diabetes Care 26:2835-2841

56. Deacon CF, Knudsen LB, Madsen K, Wiberg FC, Jacobsen O, Holst JJ (1998) Dipeptidyl peptidase IV resistant analogues of glucagon-like peptide-1 which have extended metabolic stability and improved biological activity. Diabetologia 41:271-278

57. Deacon CF, Pridal L, Klarskov L, Olesen M, Holst JJ (1996) Glucagon-like peptide 1 undergoes differential tissue-specific metabolism in the anesthetized pig. Am J Physiol 271:E458E464

58. Edwards CM, Stanley SA, Davis R et al (2001) Exendin-4 reduces fasting and postprandial glucose and decreases energy intake in healthy volunteers. Am J Physiol Endocrinol Metab 281:E155-E161

59. Erspamer V, Melchiorri P, Broccardo M et al (1981) The braingut-skin triangle: new peptides. Peptides 2 (Suppl 2):7-16

60. Tatemoto K, Mutt V (1980) Isolation of two novel candidate hormones using a chemical method for finding naturally occurring polypeptides. Nature 285:417-418

61. Eng J, Andrews PC, Kleinman WA, Singh L, Raufman JP (1990) Purification and structure of exendin-3, a new pancreatic secretagogue isolated from Heloderma horridum venom. J Biol Chem 265:20259-20262

62. Eng J, Kleinman WA, Singh L, Singh G, Raufman JP (1992) Isolation and characterization of exendin-4, an exendin-3 analogue, from Heloderma suspectum venom. Further evidence for an exendin receptor on dispersed acini from guinea pig pancreas. J Biol Chem 267:7402-7405

63. Raufman JP, Singh L, Singh G, Eng J (1992) Truncated glucagon-like peptide-1 interacts with exendin receptors on dispersed acini from guinea pig pancreas. Identification of a mammalian analogue of the reptilian peptide exendin-4. J Biol Chem 267:21432-21437

64. Goke R, Fehmann HC, Linn T et al (1993) Exendin-4 is a high potency agonist and truncated exendin-(9-39)-amide an antagonist at the glucagon-like peptide 1-(7-36)-amide receptor of insulin-secreting beta-cells. J Biol Chem 268:19650-19655

65. Raufman JP, Singh L, Eng J (1991) Exendin-3, a novel peptide from Heloderma horridum venom, interacts with vasoactive intestinal peptide receptors and a newly described receptor on dispersed acini from guinea pig pancreas. Description of exendin-3(9-39) amide, a specific exendin receptor antagonist. J Biol Chem 266:2897-2902

66. Chen YE, Drucker DJ (1997) Tissue-specific expression of unique mRNAs that encode proglucagon-derived peptides or exendin 4 in the lizard. J Biol Chem 272:4108-4115

67. Kolterman OG, Kim DD, Shen L et al (2005) Pharmacokinetics, pharmacodynamics, and safety of exenatide in patients with type 2 diabetes mellitus. Am J Health Syst Pharm 62:173-181 
68. Buse JB, Henry RR, Han J, Kim DD, Fineman MS, Baron AD (2004) Effects of exenatide (exendin-4) on glycemic control over 30 weeks in sulfonylurea-treated patients with Type 2 diabetes. Diabetes Care 27:2628-2635

69. Defronzo RA, Ratner RE, Han J, Kim DD, Fineman MS, Baron AD (2005) Effects of exenatide (exendin-4) on glycemic control and weight over 30 weeks in metformin-treated patients with type 2 diabetes. Diabetes Care 28:1092-1100

70. Kendall DM, Riddle MC, Rosenstock J et al (2005) Effects of exenatide (exendin-4) on glycemic control over 30 weeks in patients with type 2 diabetes treated with metformin and a sulfonylurea. Diabetes Care 28:1083-1091

71. Degn KB, Juhl CB, Sturis J et al (2004) One week's treatment with the long-acting glucagon-like peptide 1 derivative liraglutide (NN2211) markedly improves 24-h glycemia and alphaand beta-cell function and reduces endogenous glucose release in patients with type 2 diabetes. Diabetes 53:1187-1194

72. Knudsen LB, Agersø H, Bjenning C et al (2001) GLP-1 analogs as novel compounds for the treatment of type 2 diabetes: selection of NN2211 for clinical development. Drugs of the Future 26:677-685

73. Madsbad S, Schmitz O, Ranstam J, Jakobsen G, Matthews DR (2004) Improved glycemic control with no weight increase in patients with type 2 diabetes after once-daily treatment with the long-acting glucagon-like peptide 1 analog liraglutide (NN2211): a 12-week, double-blind, randomized, controlled trial. Diabetes Care 27:1335-1342

74. Nauck M, Hompesch M, Filipczak R et al (2004) Liraglutide as add-on to metformin in type 2 diabetes: significant improvement in glycaemic control with a reduction in body weight compared with glimepiride. Diabetologia 47:A281 (Abstract)

75. Deacon CF, Hughes TE, Holst JJ (1998) Dipeptidyl peptidase IV inhibition potentiates the insulinotropic effect of glucagonlike peptide 1 in the anesthetized pig. Diabetes 47:764-769

76. Pospisilik JA, Stafford SG, Demuth HU et al (2002) Long-term treatment with the dipeptidyl peptidase IV inhibitor P32/98 causes sustained improvements in glucose tolerance, insulin sensitivity, hyperinsulinemia, and beta-cell glucose responsiveness in VDF (fa/fa) Zucker rats. Diabetes 51:943-950

77. Sudre B, Broqua P, White RB et al (2002) Chronic inhibition of circulating dipeptidyl peptidase IV by FE 999011 delays the occurrence of diabetes in male Zucker diabetic fatty rats. Diabetes 51:1461-1469

78. Reimer MK, Holst JJ, Ahren B (2002) Long-term inhibition of dipeptidyl peptidase IV improves glucose tolerance and preserves islet function in mice. Eur J Endocrinol 146:717-727

79. Nagakura T, Yasuda N, Yamazaki K et al (2001) Improved glucose tolerance via enhanced glucose-dependent insulin secretion in dipeptidyl peptidase IV-deficient Fischer rats. Biochem Biophys Res Commun 284:501-506

80. Marguet D, Baggio L, Kobayashi T et al (2000) Enhanced insulin secretion and improved glucose tolerance in mice lacking CD26. Proc Natl Acad Sci USA 97:6874-6879

81. Mitani H, Takimoto M, Kimura M (2002) Dipeptidyl peptidase IV inhibitor NVP-DPP728 ameliorates early insulin response and glucose tolerance in aged rats but not in aged Fischer 344 rats lacking its enzyme activity. Jpn J Pharmacol 88:451-458
82. Mitani H, Takimoto M, Hughes TE, Kimura M (2002) Dipeptidyl peptidase IV inhibition improves impaired glucose tolerance in high-fat diet-fed rats: study using a Fischer 344 rat substrain deficient in its enzyme activity. Jpn J Pharmacol $88: 442-450$

83. Yasuda N, Nagakura T, Yamazaki K, Inoue T, Tanaka I (2002) Improvement of high fat-diet-induced insulin resistance in dipeptidyl peptidase IV-deficient Fischer rats. Life Sci 71:227238

84. Conarello SL, Li Z, Ronan J et al (2003) Mice lacking dipeptidyl peptidase IV are protected against obesity and insulin resistance. Proc Natl Acad Sci USA 100:6825-6830

85. Ahren B, Simonsson E, Larsson H et al (2002) Inhibition of dipeptidyl peptidase IV improves metabolic control over a 4-week study period in type 2 diabetes. Diabetes Care 25 : 869-875

86. Ahren B, Landin-Olsson M, Jansson PA, Svensson M, Holmes D, Schweizer A (2004) Inhibition of dipeptidyl peptidase-4 reduces glycemia, sustains insulin levels, and reduces glucagon levels in type 2 diabetes. J Clin Endocrinol Metab 89: 2078-2084

87. Ahren B, Gomis R, Standl E, Mills D, Schweizer A (2004) Twelve- and 52-week efficacy of the dipeptidyl peptidase IV inhibitor LAF237 in metformin-treated patients with type 2 diabetes. Diabetes Care 27:2874-2880

88. Brandt I, Joossens J, Chen X et al (2005) Inhibition of dipeptidyl-peptidase IV catalyzed peptide truncation by Vildagliptin ((2S)-\{[(3-hydroxyadamantan-1-yl)amino]acetyl $\}$-pyrrolidine-2-carbonitrile). Biochem Pharmacol 70:134-143

89. Mari A, Sallas WM, He YL et al (2005) Vildagliptin, a dipeptidyl peptidase-IV inhibitor, improves model-assessed beta-cell function in patients with type 2 diabetes. J Clin Endocrinol Metab 90:4888-4894

90. Deacon CF (2005) MK-431 (Merck). Curr Opin Investig Drugs $6: 419-426$

91. Egan JM, Bulotta A, Hui H, Perfetti R (2003) GLP-1 receptor agonists are growth and differentiation factors for pancreatic islet beta cells. Diabetes Metab Res Rev 19:115-123

92. Xu G, Stoffers DA, Habener JF, Bonner-Weir S (1999) Exendin-4 stimulates both beta-cell replication and neogenesis, resulting in increased beta-cell mass and improved glucose tolerance in diabetic rats. Diabetes 48:2270-2276

93. Stoffers DA, Kieffer TJ, Hussain MA et al (2000) Insulinotropic glucagon-like peptide 1 agonists stimulate expression of homeodomain protein IDX-1 and increase islet size in mouse pancreas. Diabetes 49:741-748

94. Zhou J, Wang X, Pineyro MA, Egan JM (1999) Glucagon-like peptide 1 and exendin-4 convert pancreatic AR42J cells into glucagon- and insulin-producing cells. Diabetes 48:2358-2366

95. Buteau J, El-Assaad W, Rhodes CJ, Rosenberg L, Joly E, Prentki M (2004) Glucagon-like peptide-1 prevents beta cell glucolipotoxicity. Diabetologia 47:806-815

96. Brubaker PL, Drucker DJ (2004) Minireview: Glucagon-like peptides regulate cell proliferation and apoptosis in the pancreas, gut, and central nervous system. Endocrinology 145: 2653-2659 